\title{
Figures and Maps
}

FIGURES

I. Multistory manufacturing firm 15

2. Kreischer and Sons' Brickmaking I8-I9

3. Manhattan manufactory, i 85326

4. New Jersey factory, I 87427

5. The Novelty Ironworks from the East River, c. I848 44

6. Floorplan of the Novelty Works, I 85 I 45

7. Hoe's ten-cylinder rotary press, c. I $8575 I$

8. The Gordon jobber, I 85854

9. New York City and national population, I 85075

Io. Sex by age, New York City, I 855 IO4

I I . Average monthly temperature, New York City and England II I

I 2. Orders of a clothing firm, I 844-I845 II 2

I3. Sales of a soapmaker, I8I5-I8I7 II3

I4. Sales of a carpetmaker, I838-i839 II3

I 5. Employment in combmaking, I 843-I 846 and I 856 I I4

I6. Employment in typecasting, I859-I863 I I4

I7. Employment in construction, I8I5-I820 II7

I 8. Forges at the Novelty Works, I 85 I I26

I9. W. S. and C. H. Thomson's Hoop Skirt Manufactory, I859 I35

20. Monthly average temperature in New York City and persons relieved, I850I 854 I66

2 I. Tenement floor plans, I864 I70 
22. Immigration and deathrate, New York, I820-I860 I83

23. Frank Chanfrau as Mose 224

24. John Morrissey 233

25. "The Peanut Stand" 268

\section{MAPS}

I. New York City region, I860 I6

2. New York City wards, I 86029

3. Percentage of jobs in manufacturing compared to percentage of residents, I $860 \quad$ I95

4. Ratio of persons to rooms, I 860203

5. New York City wards with the highest percentage of Germans, Irish, and natives, I 855205

6. Percentage of the population aged 20-35, I 855206

7. Sex distribution by ward, I 855207

8. Males aged $20-35$, as percentage of the total population, I 855208 